\title{
Protective and Curative Antiobesity Potential of Lemon Peel Extract in Rats fed a High Fat Diet: Mechanism of Action
}

\author{
Magda K. Ezz ${ }^{1}$, Azza A. Atef ${ }^{1 *}$, Nagwa I. Hassanein ${ }^{2}$ and Zeinab M. B. Salah ${ }^{1}$ \\ ${ }^{1}$ Department of Biochemistry, Faculty of Science, Ain Shams University, Cairo, Egypt, \\ ${ }^{2}$ Department of Biochemistry and Nutrition, Faculty of Girls, Ain Shams University, Cairo, Egypt
}

\section{A R T ICLE INFO}

Article history:

Received 26 March 2016

Accepted 11 June 2016

Keywords:

Lemon peel extract;

$A C O$

$G 6 P D$

$M A C D$

leptin

adiponectin.

\begin{abstract}
A B S T R A C T
The aim of this study was to investigate the effect of dietary lemon peel extract (LPE) on high fat diet-induced obesity in rats. Some of the LPE mechanism of action was also elucidated. Fifty adult rats were divided into five groups: 1) normal control, 2) lemon peel extract group supplemented with $0.5 \mathrm{~g} \% \mathrm{LPE}$ for 12 weeks, 3) high fat diet-fed for 12 weeks, 4) preventive group fed on high fat diet supplemented with LPE $0.5 \mathrm{~g} \%$ for 12 weeks and 5) therapeutic group fed on high fat diet for 12 weeks then supplemented with LPE $0.5 \mathrm{~g} \%$ further 6 weeks. Body weight gain, food intake, feed efficiency ratio, serum lipid profile except HDL-C, serum glucose, serum insulin, erythrocytes glucose-6-phosphate dehydrogenase activity and serum leptin were significantly suppressed in LPEtreated groups compared to the high fat diet-fed group. Also, LPE up-regulated acyl coenzyme A oxidase (ACO) and medium chain acyl coenzyme A dehydrogenase (MCAD) activities in serum of treated groups compared to the high fat diet-fed group. Additionally mRNA expression of ACO in the liver was up-regulated in LPE-treated groups as compared to the high fat diet group. Furthermore, oral supplementation of LPE resulted in improved serum total antioxidant capacity and serum adiponectin. These findings demonstrate that LPE prevent body weight gain and fat accumulation through improvement of lipid metabolism by up-regulating the activities of MCAD and ACO while down regulating the activity of glucose 6 phosphate dehydrogenase. In this context, the preventive effect of LPE was more pronounced than the therapeutic effect.
\end{abstract}

\section{Introduction}

The incidence of obesity and its related metabolic disorders has escalated dramatically worldwide, including the populations living in the developing countries, and is becoming a key public health issue with a massive burden to the healthcare system [1]. Obesity increases the morbidity rates of a number of metabolic disorders, such as type 2 diabetes mellitus, hypertension and cardiovascular diseases ${ }^{[1]}$. Obesity is a disease characterized by excess body weight, associated with a state of chronic subclinical inflammation, caused by an increased secretion of adipokines such as leptin and adiponectin that modulate certain responses in the body ${ }^{[2]}$. In Egypt, obesity is rising among young adults, overtime these conditions, especially if associated with poor dietary habits, smoking or physical inactivity, will lead to cardiovascular diseases later in adulthood ${ }^{[3]}$.

* Corresponding author.

E-mail address: azza_atef@hotmail.com
Because diets containing high-fat foods are becoming common, it is necessary to find suitable alternatives, such as phytochemicals, to ameliorate the effect of a high fat diet, thereby reducing the risk associated with obesity [4].

Over the years, many medications have been used to manage obesity, but most of them are now withdrawn due to their serious adverse effects ${ }^{[5]}$.

In recent years, much attention has been paid to vegetables and fruits as novel protective and even therapeutic strategies for management of obesity and several diseases due to their phytochemical constituents [6]. Phytochemicals are known to possess antioxidant properties with the effective anti-inflammatory, antiallergic, hepatoprotective, antithrombotic, antiviral and anticarcinogenic activities with low adverse effects [7]. Phytochemicals such as flavonoids may help to prevent or reduce obesity through the regulation of different molecular pathways ${ }^{[8]}$. 
Citrus fruits contain various kinds of flavonoids such as flavonone glycosides and polymethoxy flavones [9]. Lemon plant (Citrus aurantifolia) belongs to the Rutaceae family, and is the third most important Citrus species after orange and mandarin. Crude extracts of different parts of lemon (leaves, stem, root and flower) rich in flavonoid glycosides and polyphenols that have a number of positive health effects in the prevention of lifestyle-related diseases and have antiobesity effects ${ }^{[9-}$ 10]

Previous studies have demonstrated the effects of Citrus limon flavonoids on lipid and glucose metabolism, specifically on lipid catabolism, glucose transport, the insulin-receptor function, and peroxisome proliferatoractivated receptors (PPARs) activation, all of which play essential roles in weight control ${ }^{[11-12]}$.

In this study, the effect of supplementation with LPE on high fat diet-induced obesity in rats was investigated. To achieve this aim, the regulatory effect of LPE administration on lipid profile, glucose, insulin, leptin, adiponectin and some lipid metabolism regulatory enzymes has been explored. In addition, LPE effect on the mRNA expression of the acyl coenzyme A oxidase (ACO) gene was evaluated.

\section{Materials and Methods}

Preparation of Lemon Peel Extract

Fresh lemons (Citrus aurantifolia) were obtained from the local market, washed with distilled water; then dried at $60^{\circ} \mathrm{C}$, grounded peeled and finely extract was diluted in appropriate concentration 50\% with $70 \%$ methanol a shaking water bath at $60^{\circ} \mathrm{C}$. The extract was clarified by centrifugation at 3000 r.p.m for 20 minutes followed by four times filtrations. Finally, the supernatant was stored in the dark ${ }^{[13]}$. The constituents of LPE were analyzed by high performance liquid chromatography (HPLC).

\section{RP-HPLC Analysis}

The Polyphenolic components of LPE were identified by Agilent 1100 series Model HPLC apparatus (Germany) was coupled with an UV-V is multiwavelength detector set at $280 \mathrm{~nm}$. Chromatographic separation of dissolved extracts was performed on a Zorbax SB-C18 column (Agilent Technologies, USA). The mobile phase composed of acetonitrile: phosphate buffer $(\mathrm{pH} 4.5,0.01 \mathrm{M})$ in the ratio of $(65: 35 ; \mathrm{v} / \mathrm{v})$ at a flow rate of $0.5 \mathrm{ml} / \mathrm{min}$. Five $\mu \mathrm{g}$ of the stem extract were diluted in $1 \mathrm{ml}$ of methanol (HPLC grade) using the protocol described by Miyake ${ }^{[14]} \&$ Perdetzoglou et al. ${ }^{15]}$ which occurred in Faculty of Agriculture Research, Cairo University. The injection volume was twenty $\mu l$ and peaks were identified by comparing the retention times of the samples with those of the known standards.

\section{Experimental Design and Dietary Treatment}

Fifty adult male Swiss albino rats, weighing 100-120 g obtained from Helwan farm, Egypt, were used throughout this study. Rats were housed individually in stainless steel cages fitted with wire mesh bottoms and fronts in care of Laboratory animal house, Entomology
Department, Faculty of Science, Ain Shams University, Cairo, Egypt. After one week as an adaptation period, the animals were divided into five equal groups (10 rats each) as follows:

Normal control group (NC): rats were fed a standard diet AIN-76 diet ${ }^{[11]}$ (65\% carbohydrate, 5\% fat, $20 \%$ protein, vitamins, minerals and fiber 5\%) for 12 weeks.

Lemon peel extract group (LPE): rats were fed a standard diet enriched with $0.5 \mathrm{~g} \%$ (w/w) LPE for 12 weeks.

High fat diet group (HFD): rats were fed a high fat AIN-76 diet ${ }^{[11]}$ (55\% carbohydrate, $15 \%$ fat, $20 \%$ protein, vitamins, minerals and fiber $5 \%$ ) for 12 weeks serving as negative control.

Preventive group: rats were fed a high fat diet enriched with $0.5 \mathrm{~g} \%$ (w/w) LPE for 12 weeks.

Therapeutic group: rats were fed a high fat diet for 12 weeks, then they were fed a high fat diet supplemented with LPE $0.5 \mathrm{~g} \%$ (w/w) further 6 weeks.

\section{Body Weight, Food Intake and Blood Collection}

The body weight of each rat was recorded twice weekly. Food intake was measured 3 times per week and the averages of food consumed were calculated weekly. At the end of the experimental period, rats were fasted for 12 hours, anesthetized and sacrificed. Blood samples were collected from the portal hepatic vein in dry clean centrifuge tubes with and without EDTA, for whole blood and serum samples, respectively. Serum samples were stored at $-80^{\circ} \mathrm{C}$ until analysis.

\section{Biochemical Assays}

Feed efficiency ratio was calculated based on the following formula: Feed efficiency ratio $=$ body weight gain/total food intake during experiment period [16]. Serum Total cholesterol (TC), high density lipoproteincholesterol (HDL-C), triglycerides (TG) and fasting glucose levels were estimated using commercial kits supplied by Reactivos GPL, Espana according to the methods of Natio ${ }^{[17 a]} \&$ Natio ${ }^{[18 b]} \&$ Buccolo and David ${ }^{[19]} \&$ Trinder ${ }^{[20]}$, respectively. Atherogenic index (AI) was calculated based on the following formula: $\mathrm{AI}=(\mathrm{TC}-\mathrm{HDL}-\mathrm{C}) / \mathrm{HDL}^{-\mathrm{C}}{ }^{[21]}$. Serum low density lipoprotein-cholesterol (LDL-C) and very low density lipoprotein-cholesterol (VLDL-C) were calculated by Friedewald's and Delong's formula ${ }^{[22-23]}$, respectively. Serum phospholipids were estimated using a commercial kit supplied by Spectrum-Diagnostic, Egypt, according to the methods of Meiattini ${ }^{[24]}$. Serum insulin was measured by rat enzyme-linked immunosorbent assay (ELISA) kit as described by Paintlia et al. ${ }^{[25]}\left(\right.$ RayBio $^{\circledR}$, Egy chem. Co. for lab technology). The homeostasis model assessment of insulin resistance (HOMA-IR) index was calculated based on the following formula: HOMA-IR= fasting insulin $(\mu \mathrm{UI} / \mathrm{mL}) \times$ fasting glucose $(\mathrm{mM}) / 22.5^{[26]}$. Serum leptin and adiponectin levels were determined using rat ELISA kits according to the methods of Nemzek et al. ${ }^{[27]}$ \& Yamauchi et al. ${ }^{[28]}$, respectively $\left(\right.$ RayBio $^{\circledR}$, Egy chem. Co. for lab technology). 
Serum total antioxidant capacity was estimated using a kit supplied by Spectrum-Diagnositc, Egypt, according to the methods of Koracevic ${ }^{[29]}$. Glucose-6-phosphate dehydrogenase (G6PD) activity was determined in erythrocytes using a kit supplied by Bio-Diagnostic, Egypt, according to the methods of Kornberg ${ }^{[30]}$. ACO and MCAD activities were measured in serum using ELISA kits $\left(\right.$ Abcam $^{\circledR}$, Egy KEMET Medical Office) according to the methods of Osumi et al. ${ }^{[31]}$ \& Koster et al. ${ }^{[32]}$, respectively.

\section{RNA Isolation from Liver and Real Time PCR}

Total RNA from the liver tissue was extracted with BIOZOL $^{\mathrm{TM}}$ Reagent (BioFlux, South San Francisco, U.S.A) ${ }^{[33]}$. One $\mu \mathrm{g}$ of extracted RNA was used for reverse transcription by RevertAid ${ }^{\mathrm{TM}}$ First Strand cDNA synthesis $\mathrm{Kit}^{\mathrm{TM}}$ (Fermentas life science Co, Van Allen Way, Canada) ${ }^{[34]}$ using oligo (dt) primer for $1 \mathrm{hr}$ at $42^{\circ} \mathrm{C}$ according to manuifacturer instructions ${ }^{[34]}$. The relative expression of the ACO gene was analyzed by STRATAGENE MX3000P machine maxima SYBR Green/ROX qPCR master mix utilizing ACO gene specific (NCBI accession no. NM_017340) primer (5'CTTTCTTGCTTGCCTTCCTTCTCC-3', Forward p) and (5'- GCCGTTTCACCGCCTCGTA-3', Reverse p). And including GAPDH gene as a reference gene to normalize the expression data (5'TGCACCACCAACTGCTTAGC-3', Forward p) and (5'-GGCATGGACTGTGGTCATGAG-3', Reverse p) with cycling conditions for both genes as follows: denaturing step at $95^{\circ} \mathrm{C}$ for $2 \mathrm{~min}$, followed by 40 cycles of $95^{\circ} \mathrm{C}$ for $15 \mathrm{~s}$, and $60^{\circ} \mathrm{C}$ for $1 \mathrm{~min}{ }^{[35]}$. Melting curve analysis was done to ensure specific amplification (Fig. 1). The fold change for ACO gene expression calculated compared to housekeeping (GAPDH) gene expression for each group.

The relative expression and fold changes were calculated according to the formula $2^{-\Delta \Delta \mathrm{Ct}}$ method $^{[36]}$.

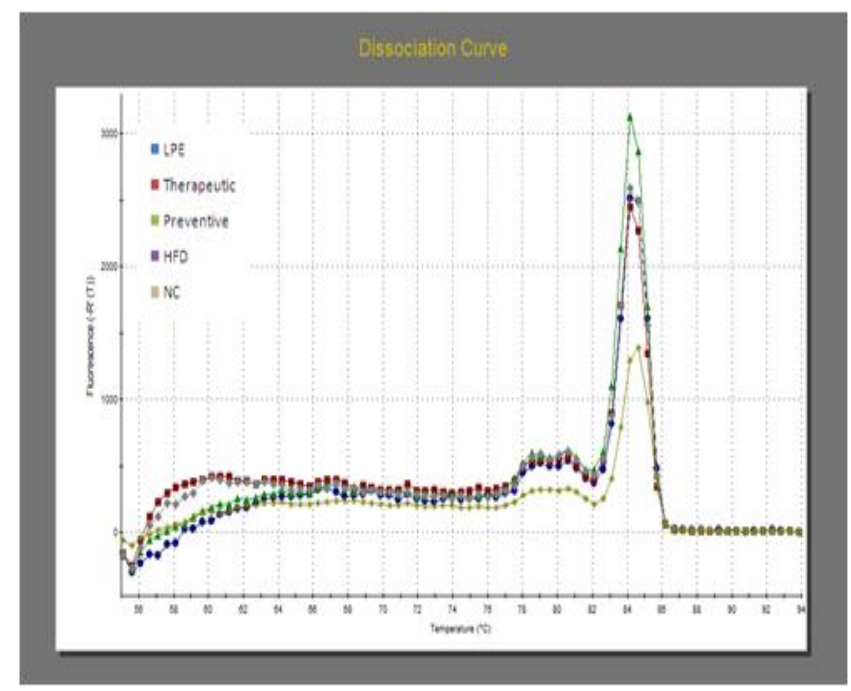

Fig (1): Melting curve analysis for ACO gene expression.

\section{Histological Studies}

Immediately after scarifying rats, livers were removed, washed with chilled physiological saline $(0.9 \% \mathrm{w} / \mathrm{v})$, dried between filter papers then stored in $10 \%$ neutral buffered formalin for histological examination. The fixed tissues were then cut into suitable sections and processed for preparation of $5 \mu \mathrm{m}$-thick paraffin sections. These sections were sequentially stained with Hematoxylin and Eosin. The slides were examined and photographed under a light microscope at a magnification power of $\mathrm{x} 200$.

\section{Statistical Analysis}

The results were expressed as mean $+\mathrm{SD}$ of ten rats per group and statistical significance was evaluated by one way analysis of variance (ANOVA) post hoc Duncan's test to determine the significant differences between means using SPSS program (version 19.0). Values were considered statistically significant at $p$ value less than 0.05 .

\section{Results}

\section{Lemon Peel Polyphenols Extract}

Qualitative and quantitative determination of citrus LPE constitutents were performed by RP-HPLC analysis. The chromatogram of lemon peel methanolic extract as shown in Table (1) and Fig. (2) identified eleven polyphenolic compounds; pyrogallic (39.1 mg/100g), salicylic acid $(11.26 \mathrm{mg} / 100 \mathrm{~g})$, luteoline $(6.21 \mathrm{mg} / 100 \mathrm{~g})$, $\rho$-coumaric acid $(3.92 \mathrm{mg} / 100 \mathrm{~g})$, euganol $(1.23$ $\mathrm{mg} / 100 \mathrm{~g})$, caffeic acid $(1.19 \mathrm{mg} / 100 \mathrm{~g})$, resorcinol (1.05 $\mathrm{mg} / 100 \mathrm{~g})$, quercetin $(0.84 \mathrm{mg} / 100 \mathrm{~g}), \rho$-hydroxy benzoic acid $(0.77 \mathrm{mg} / 100 \mathrm{~g})$, chrysin $(0.50 \mathrm{mg} / 100 \mathrm{~g})$ and luteolin-3-methoxy-7-rutinoside $(0.40 \mathrm{mg} / 100 \mathrm{~g})$.

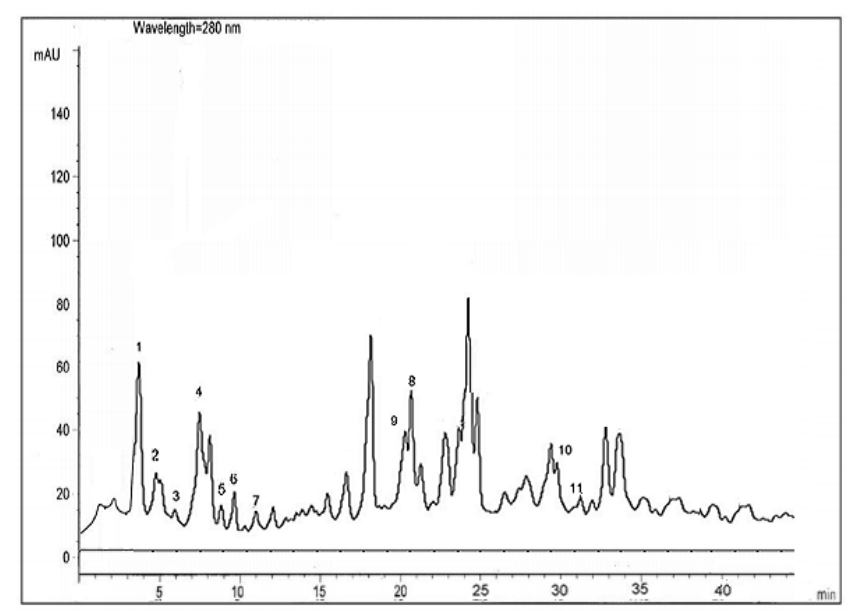

Fig (2): HPLC Chromatogram analysis of lemon peel extract at $280 \mathrm{~nm}$. The presented numbers on the chart indicats the lemon peel componants as follows: 1: pyrogallic; 2 :caffeic acid; 3: euganol ; 4: $\rho$-coumaric acid; 5: $\rho$-hydroxy benzoic acid; 6: resorcinol; 7: salicylic acid; 8: luteoline; 9:quercetin; 10: chrysin; 11: luteolin-3methoxy-7-rutinoside. 
Table 1: HPLC analysis of lemon peel extract (LPE).

\begin{tabular}{|c|c|c|c|}
\hline Peak No. & $\mathbf{t}_{\mathbf{R}}(\mathbf{m i n})$ & Compound & mg/ 100 g LPE \\
\hline $\mathbf{1}$ & 3.4 & Pyrogallic & 39.1 \\
\hline $\mathbf{2}$ & 5.3 & Caffeic acid & 1.19 \\
\hline $\mathbf{3}$ & 6.0 & Euganol & 1.23 \\
\hline $\mathbf{4}$ & 7.8 & Salicylic acid & 0.77 \\
\hline $\mathbf{5}$ & 8.1 & $\rho$-hydroxy benzoic acid & 1.05 \\
\hline $\mathbf{6}$ & 8.9 & Resorcinol & 3.92 \\
\hline $\mathbf{7}$ & 13.4 & $\rho$-coumaric acid & 6.21 \\
\hline $\mathbf{8}$ & 18.0 & Luteoline & 0.84 \\
\hline $\mathbf{9}$ & 18.3 & Quercetin & 0.50 \\
\hline $\mathbf{1 0}$ & 30.2 & Chrysin & 0.40 \\
\hline $\mathbf{1 1}$ & 31.1 & Luteolin-3-meth-oxy-7-rutinoside & \\
\hline
\end{tabular}

$t_{\mathrm{R}:}$ time retention

\section{Effect of Lemon Peel Extract on Body Weight, Food Intake and Feed Efficiency Ratio}

Table (2) showed that rats fed on a standard diet and supplement with LPE had non significant changes in body weight, food intake or feed efficiency ratio compared to the normal control group. The high fat diet group showed highly significant increases $(P<0.01)$ in body weight and food intake by 82.44 and $45.63 \%$, respectively, and a significant elevation $(P<0.05)$ in feed efficiency by $53.75 \%$ compared to the normal control group. The LPE-treated groups showed significant decreases $(P<0.05)$ in body weight, food intake and feed efficiency ratio by $35.30,16.02$ and $34.31 \%$, respectively, for the preventive group, and by 33.63 , 9.21 and $32.52 \%$ for the therapeutic group, respectively, as compared to the HFD-group. However, comparing the LPE-treated groups with the normal control group showed significant increases $(P<0.05)$ in body weight and food intake by 18.04 and $22.30 \%$, respectively, in the preventive group, and by 21.09 and $32.22 \%$, respectively, in the therapeutic group, while showing a non significant change in feed efficiency ratio.

\section{Effect of Lemon Peel Extract on Serum Lipid Profile}

Table (3) revealed that supplementation with LPE to standard diet resulted in a moderate hypolipidemic effect manifested by the significant decrease in both serum TG and VLDL-C by 13.88 and $15.44 \%$, respectively, compared to normal rats.

The HFD-group showed significant increases $(P<0.05)$ in serum TC, TG, VLDL-C, LDL-C, AI and phospholipids by $112.96,100.17,100.14,469.24,455.77$ and $176.96 \%$, respectively, while showing a significant decrease $(P<0.05)$ in HDL-C by $35.33 \%$ compared to the normal control group. In LPE-treated groups, there were significant decreases $(P<0.05)$ in serum TC, TG, VLDLC, LDL-C, AI and phospholipids levels, by 41.52, 22.12, $22.11,80.38,78.03$ and $21.23 \%$, respectively, in the preventive group, and by $7.84,15.12,15.11,29.97,61.07$ and $16.96 \%$, respectively, in the therapeutic group compared to the HFD-group. In contrast, HDL-C level was significantly increased $(P<0.05)$ by $72.42 \%$ in the preventive group and by $90.59 \%$ in the therapeutic group as compared to the HFD-group.

Table 2: Weight gain, food intake and feed efficiency ratio in different studied groups.

\begin{tabular}{|l|c|c|c|}
\hline Parameters & \multirow{2}{*}{ Weight gain $(\mathbf{g})$} & $\begin{array}{c}\text { Food intake } \\
\text { (g/day) }\end{array}$ & Feed efficiency ratio \\
\hline NC & $61.63 \pm 8.21$ & $13.50 \pm 0.93$ & $4.00 \pm 0.54$ \\
\hline LPE & $64.50 \pm 9.17$ & $15.31 \pm 1.58$ & $4.02 \pm 0.96$ \\
\hline HFDange from NC & 4.66 & $13.41 \uparrow$ & $0.50 \uparrow$ \\
\%Change from NC & $112.44 \pm 6.20^{\mathrm{a}}$ & $19.66 \pm 1.26^{\mathrm{a}}$ & $6.15 \pm 1.41^{\mathrm{a}}$ \\
\hline Preventive & 82.44 & 45.63 & 4.75 \\
\%Change from NC & $72.75 \pm 6.01^{\mathrm{ab}}$ & $16.51 \pm 2.37^{\mathrm{ab}}$ & 1.00 \\
\%Change from PC & 18.04 & 22.30 & -34.31 \\
\hline Therapeutic & -35.30 & -16.02 & $4.15 \pm 0.61^{\mathrm{b}}$ \\
\%Change from NC & $74.63 \pm 7.46^{\mathrm{b}}$ & $17.85 \pm 0.65^{\mathrm{a}}$ & 3.75 \\
\%Change from PC & 21.09 & 32.22 & -32.52 \\
\hline
\end{tabular}

Data are represented as mean \pm SD of 10 rats. Each value is considered statistically significant at $p<0.05$.

${ }^{\mathrm{a}}$ Statistically significant from normal control group; ${ }^{\mathrm{b}}$ Statistically significant from HFD-group.

LPE: Lemon peel extract; HFD: High fat diet; NC: Normal Control; PC: Positive Control; (g/day): Average of food intake through 12 weeks. 
Table 3: Change in serum lipid profile in the different studied groups.

\begin{tabular}{|c|c|c|c|c|c|c|c|}
\hline Parameters & \multirow{2}{*}{$\underset{(\mathrm{mg} / \mathrm{dl})}{\mathbf{T}}$} & \multirow{2}{*}{$\begin{array}{c}\text { TC } \\
(\mathrm{mg} / \mathrm{dl})\end{array}$} & \multirow{2}{*}{$\begin{array}{l}\text { VLDL-C } \\
\text { (mg/dl) }\end{array}$} & \multirow{2}{*}{$\begin{array}{l}\text { LDL-C } \\
(\mathrm{mg} / \mathrm{dl})\end{array}$} & \multirow{2}{*}{$\begin{array}{l}\text { HDL-C } \\
(\mathrm{mg} / \mathrm{dl})\end{array}$} & \multirow{2}{*}{$\begin{array}{c}\text { Atherogenic } \\
\text { Index }\end{array}$} & \multirow{2}{*}{$\begin{array}{c}\text { Phospholipids } \\
(\mathrm{mg} / \mathrm{dl})\end{array}$} \\
\hline Groups & & & & & & & \\
\hline NC & & & & & & & $103.13 \pm 6$ \\
\hline $\begin{array}{l}\text { LPE } \\
\text { \% Cha }\end{array}$ & 50 & 1.9 & & $\begin{array}{r}20.5 \\
-\end{array}$ & $\begin{array}{r}52.17 \pm+ \\
6.23\end{array}$ & $\begin{array}{r}0.96+ \\
-7 .\end{array}$ & 3.13 \\
\hline & $\begin{array}{c}288.50 \pm 10.17^{\mathrm{a}} \\
100.17\end{array}$ & $\begin{array}{c}211.79 \pm 8.59^{a} \\
112.96\end{array}$ & $\begin{array}{c}57.70 \pm 2.03^{\mathrm{a}} \\
100.14\end{array}$ & $\begin{array}{c}122.33 \pm 10.53^{\mathrm{a}} \\
469.24\end{array}$ & $\begin{array}{c}31.76 \pm 4.45^{a} \\
-35.33\end{array}$ & & $\begin{array}{c}285.63 \pm 58.26^{a} \\
176.96\end{array}$ \\
\hline $\begin{array}{l}\text { Preventive } \\
\text { \% Change from NC } \\
\text { \% Change from PC }\end{array}$ & $\begin{array}{c}55.89 \\
-22.12 \\
\end{array}$ & $\begin{array}{c}123.86+3.95^{\mathrm{a}} \\
24.54 \\
-41.52 \\
\end{array}$ & \begin{tabular}{c|}
55.88 \\
-22.11 \\
\end{tabular} & \begin{tabular}{|c}
$24.00 \pm 3.44^{\mathrm{ab}}$ \\
11.68 \\
-80.38 \\
\end{tabular} & \begin{tabular}{|c}
$54.76 \pm 3.83^{\mathrm{ab}}$ \\
11.50 \\
72.42
\end{tabular} & $\begin{array}{c}1.27 \pm 0.12^{\mathrm{ab}} \\
22.12 \\
-78.03\end{array}$ & $\begin{array}{c}225.00 \pm 35.58^{\mathrm{ab}} \\
118.17 \\
-21.23 \\
\end{array}$ \\
\hline $\begin{array}{l}\text { Therapeutic } \\
\% \text { Change from NC } \\
\% \text { Change from PC }\end{array}$ & \begin{tabular}{|c|}
$244.88 \pm 48.36^{\mathrm{ab}}$ \\
69.90 \\
-15.12 \\
\end{tabular} & $\begin{array}{c}195.18 \pm 5.12^{\mathrm{a}} \\
96.26 \\
-7.84\end{array}$ & $\begin{array}{c}48.98 \pm 9.67^{\mathrm{ab}} \\
69.89 \\
-15.11\end{array}$ & \begin{tabular}{|c|}
$85.67 \pm 13.97^{\mathrm{ab}}$ \\
298.65 \\
-29.97
\end{tabular} & \begin{tabular}{|c|}
$60.53 \pm 5.85^{\mathrm{ab}}$ \\
23.25 \\
90.59
\end{tabular} & $\begin{array}{c}2.25 \pm 0.32^{\mathrm{ab}} \\
116.35 \\
-61.07\end{array}$ & $\begin{array}{l}129.99 \\
-16.96\end{array}$ \\
\hline
\end{tabular}

Data are represented as mean \pm SD of 10 rats. Each value is considered statistically significant at $p<0.05$.

${ }^{\mathrm{a}}$ Statistically significant from normal control group; ${ }^{\mathrm{b}}$ Statistically significant from HFD-group.

LPE: Lemon peel extract; HFD: High fat diet; NC: Normal Control; PC: Positive Control.

\section{Effect of Lemon Peel Extract on Serum Glucose, Serum Insulin and HOMA-IR}

Table (4) showed that the group of rats fed on standard diet and supplement with LPE had non significant changes in serum glucose, serum insulin and HOMA-IR compared to the normal control group.

In the HFD-group, there were significant increases $(P<0.05)$ in serum glucose level by $47.35 \%$, serum insulin and HOMA-IR by 68.21 and $124.13 \%$, respectively, compared to the normal control group. However, comparing the LPE-treated groups with the HFD-group showed significant decreases $(P<0.05)$ in serum glucose, serum insulin and HOMA-IR by 31.53 , 34.52 and $50.37 \%$, respectively, in the preventive group, and by $23.86,32.71$ and $43.30 \%$, respectively, in the therapeutic group.

Effect of Lemon Peel Extract on Serum Adiponectin and Serum Leptin Levels as well as Serum Total Antioxidant Capacity

Table (4) demonstrated that rats fed on standard diet and supplement with LPE showed non significant changes in serum leptin, serum adiponectin and serum total antioxidant capacity (TAC) compared to the normal control group.

The HFD-group showed a significant increase $(P<0.05)$ in serum leptin by $81.87 \%$, and significant decreases $(P<0.05)$ in serum adiponectin and TAC by 23.23 and $29.09 \%$, respectively, compared to the normal control group. However, comparing the LPE-treated groups with the HFD-group showed a significant decrease $(P<0.05)$ in serum leptin by $27.10 \%$ in the preventive group and by $24.12 \%$ in the therapeutic group. On the other hand, adiponectin and TAC levels showed significant increases by 18.01 and $34.61 \%$, respectively, in the preventive group, and by 9.91 and $30.77 \%$, in the therapeutic group, respectively.

\section{Effect of Lemon Peel Extract on Some Lipid- Metabolizing Enzyme Activities}

Table (5) revealed that rats fed on standard diet and supplement with LPE showed non significant changes in erythrocytes G6PD, serum ACO and serum MCAD activities compared to the normal control group.

The HFD-group showed significant increases $(P<0.05)$ in erythrocytes G6PD by $200.15 \%$, serum ACO by $563.28 \%$ and serum MCAD by $90.41 \%$, compared to the normal control group. The LPE-Treated groups showed a significant decrease $(P<0.05)$ in G6PD by $59.83 \%$ in the preventive group, and by $24.38 \%$ in the therapeutic group, while showing significant increases $(P<0.05)$ in serum ACO and MCAD by 79.78 and $167.07 \%$, respectively, in the preventive group, and by 15.97 and $49.31 \%$, respectively, in the therapeutic group as compared to the HFD-group.

Effect of Lemon Peel Extract on ACO Gene Expression Levels

Results presented in Figure (4) show a highly significant upregulation of ACO gene expression in the HFD, the preventive and the therapeutic groups, by 1.38, 1.99 and 1.48 -fold, respectively, as compared to the NC-group $(\mathrm{P}<0.001)$. Also, there was a highly significant upregulation of ACO gene expression in the preventive and the therapeutic groups, by 1.45 and 1.07 -fold, respectively, as compared to the HFD-group $(\mathrm{P}<0.001)$.

\section{Discussion}

In the present study, HPLC analysis of the phenolic compounds in the LPE revealed the presence of eleven components; pyrogallic, salicylic acid, luteoline, $\rho$ coumaric acid, euganol, caffeic acid, resorcinol, quercetin, $\rho$-hydroxy benzoic acid, chrysin and luteolin3-methoxy-7-rutinoside. Pyrogallic was the major compound, while luteolin-3-methoxy-7-rutinos was the least (Table 1). Flavonoids (Pyrogallic, quercetin, 
luteolin and chrysin) have been linked to reduce obesity ${ }^{[37]}$ and cardiovascular diseases ${ }^{[38]}$. Luteolin; a flavonoid with pharmacological benefits, including anti-oxidant, anti-inflammatory immuno-modulatory and anti-tumor effects ${ }^{[38]}$. Coumaric acid and caffeic acid are phenolic acids in many plant foods protecting against oxidative stress, inflammation, dyslipidemia and hypercoagulability ${ }^{[39]}$.
Quercetin is the strongest anti-oxidant and has powerful anti-inflammatory benefits ${ }^{[38]}$. It has many beneficial health effects including improvement of cardiovascular health, preventing obesity-related diseases and protection against osteoporosis ${ }^{[38-39]}$. Quercetin induces apoptosis and influences protein and lipid kinase signaling pathways. It is also a candidate for preventing obesityrelated diseases ${ }^{[38]}$.

Table 4: Changes in serum total antioxidant capacity, serum glucose, serum insulin, serum leptin and serum adiponectin levels as well as HOMA-IR in the different studied groups.

\begin{tabular}{|c|c|c|c|c|c|c|}
\hline Parameters & & & & & & \\
\hline Groups & & & & & & \\
\hline NC & $1.10 \pm 0.37$ & $89.31 \pm 5.46$ & $24.63 \pm 5.18$ & $5.43 \pm 1.34$ & $27.63 \pm 9.29$ & $173.58 \pm 3.70$ \\
\hline $\begin{array}{l}\text { LPE } \\
\text { \%Change from NC }\end{array}$ & $\begin{array}{c}1.16 \pm 0.17 \\
5.45 \\
\end{array}$ & $\begin{array}{c}91.55 \pm 5.09 \\
2.51\end{array}$ & $\begin{array}{c}26.88 \pm 8.48 \\
9.14 \\
\end{array}$ & $\begin{array}{c}6.08 \pm 2.09 \\
11.97 \\
\end{array}$ & $\begin{array}{c}27.88 \pm 11.37 \\
0.90\end{array}$ & $\begin{array}{c}176.97 \pm 2.40 \\
1.95\end{array}$ \\
\hline $\begin{array}{l}\text { HFD } \\
\% \text { Change from NC }\end{array}$ & $\begin{array}{c}0.78 \pm 0.19^{\mathrm{a}} \\
-29.09 \\
\end{array}$ & $\begin{array}{c}131.60 \pm 5^{.46}{ }^{\mathrm{a}} \\
47.35\end{array}$ & $\begin{array}{c}41.43 \pm 8.72^{\mathrm{a}} \\
68.21\end{array}$ & $\begin{array}{c}12.17 \pm 2.48^{\mathrm{a}} \\
124.13 \\
\end{array}$ & $\begin{array}{c}50.25 \pm 6.36^{\mathrm{a}} \\
81.87 \\
\end{array}$ & $\begin{array}{c}133.25 \pm 4.77^{\mathrm{a}} \\
-23.23\end{array}$ \\
\hline $\begin{array}{l}\text { Preventive } \\
\% \text { Change from NC } \\
\text { \%Change from PC }\end{array}$ & $\begin{array}{c}1.05 \pm 0.14^{b} \\
-4.55 \\
34.61 \\
\end{array}$ & $\begin{array}{c}90.11 \pm 3.55^{b} \\
0.90 \\
-31.53 \\
\end{array}$ & $\begin{array}{c}27.13 \pm 8.97^{a b} \\
10.15 \\
-34.52 \\
\end{array}$ & $\begin{array}{c}6.04 \pm 2.00^{\mathrm{ab}} \\
11.23 \\
-50.37 \\
\end{array}$ & $\begin{array}{c}36.63 \pm 7.60 \text { ab } \\
32.57 \\
-27.10 \\
\end{array}$ & $\begin{array}{c}157.25 \pm 4.81^{\mathrm{ab}} \\
-9.41 \\
18.01 \\
\end{array}$ \\
\hline $\begin{array}{l}\text { Therapeutic } \\
\% \text { Change from NC } \\
\text { \%Change from PC }\end{array}$ & $\begin{array}{c}1.02 \pm 0.09^{b} \\
-7.27 \\
30.77\end{array}$ & $\begin{array}{c}100.20 \pm 5.86^{\mathrm{ab}} \\
12.19 \\
-23.86\end{array}$ & $\begin{array}{c}27.88 \pm 5.17^{a b} \\
13.20 \\
-32.71\end{array}$ & $\begin{array}{c}6.90 \pm 0.92^{\mathrm{ab}} \\
27.07 \\
-43.30\end{array}$ & $\begin{array}{c}38.13 \pm 8.43 \\
38.00 \\
-24.12\end{array}$ & $\begin{array}{c}146.54 \pm 6.28^{a b} \\
-9.97 \\
9.91\end{array}$ \\
\hline
\end{tabular}

Data are represented as mean \pm SD of 10 rats. Each value is considered statistically significant at $p<0.05$.

${ }^{\mathrm{a}}$ Statistically significant from normal control group; ${ }^{\mathrm{b}}$ Statistically significant from HFD-group.

LPE: Lemon peel extract; HFD: High fat diet; TAC: Total antioxidant capacity; HOMA-IR: Homeostasis model assessment insulin resistance; NC: Normal Control; PC: Positive Control.

Table 5: Changes in the activities of erythrocytes G6PD, serum peroxisomal ACO, serum mitochondrial MCAD and blood hemoglobin level in the different studied groups.

\begin{tabular}{|c|c|c|c|c|}
\hline Parameters & \multirow{2}{*}{$\begin{array}{c}\text { G6PD } \\
\text { (U/g Hb) }\end{array}$} & \multirow{2}{*}{$\begin{array}{c}\mathrm{ACO} \\
(\mathrm{ng} / \mathrm{ml})\end{array}$} & \multirow{2}{*}{$\begin{array}{l}\text { MCAD } \\
(\mathrm{ng} / \mathrm{ml})\end{array}$} & \multirow{2}{*}{$\begin{array}{c}\mathbf{H b} \\
(\mathrm{g} / \mathrm{dl})\end{array}$} \\
\hline Groups & & & & \\
\hline $\mathrm{NC}$ & $6.71 \pm 1.10$ & $35.43 \pm 8.48$ & $10.32 \pm 2.32$ & $14.25 \pm 1.49$ \\
\hline $\begin{array}{l}\text { LPE } \\
\text { \% Change from NC }\end{array}$ & $\begin{array}{c}7.14 \pm 1.39 \\
6.41\end{array}$ & $\begin{array}{c}40.47 \pm 6.76 \\
14.23\end{array}$ & $\begin{array}{c}12.64 \pm 3.31 \\
22.48\end{array}$ & $\begin{array}{c}14.63 \pm 1.30 \\
2.67\end{array}$ \\
\hline $\begin{array}{l}\text { HFD } \\
\% \text { Change from NC }\end{array}$ & $\begin{array}{c}20.14 \pm 7.17^{\mathrm{a}} \\
200.15\end{array}$ & $\begin{array}{c}235.00 \pm 63.52^{a} \\
563.28\end{array}$ & $\begin{array}{c}19.65 \pm 9.95^{\mathrm{a}} \\
90.41\end{array}$ & $\begin{array}{c}12.25 \pm 1.49^{a} \\
-14.04\end{array}$ \\
\hline $\begin{array}{l}\text { Preventive } \\
\% \text { Change from NC } \\
\text { \%Change from PC }\end{array}$ & $\begin{array}{c}8.09 \pm 1.08^{a b} \\
20.57 \\
-59.83\end{array}$ & $\begin{array}{c}422.48 \pm 128.14^{\mathrm{ab}} \\
1092.44 \\
79.78\end{array}$ & $\begin{array}{c}52.48 \pm 36.82^{a b} \\
408.53 \\
167.07\end{array}$ & $\begin{array}{c}12.88 \pm 2.10^{\mathrm{a}} \\
-9.61 \\
5.14\end{array}$ \\
\hline $\begin{array}{l}\text { Therapeutic } \\
\text { \% Change from NC } \\
\text { \% Change from PC }\end{array}$ & $\begin{array}{c}15.23 \pm 2.05^{a b} \\
126.97 \\
-24.38\end{array}$ & $\begin{array}{c}272.52 \pm 63.20^{\mathrm{ab}} \\
699.18 \\
15.97\end{array}$ & $\begin{array}{c}29.34 \pm 11.10 \text { ab } \\
184.30 \\
49.31\end{array}$ & $\begin{array}{c}12.38 \pm 1.77^{\mathrm{a}} \\
-13.12 \\
1.06\end{array}$ \\
\hline
\end{tabular}

Data are represented as mean \pm SD of 10 rats. Each value is considered statistically significant at $p<0.05$.

${ }^{\mathrm{a}}$ Statistically significant from normal control group at $p<0.05 ;{ }^{\mathrm{b}}$ Statistically significant from HFD-group at $p<0.05$.

LPE: Lemon peel extract; HFD: High fat diet; G6PD: Glucose-6-phosphate dehydrogenase; ACO: Acyl coenzyme A oxidase;

MCAD: Medium chain acyl coenzyme A dehydrogenase; Hb:Hemoglobin; NC: Normal Control; PC: Positive Control 


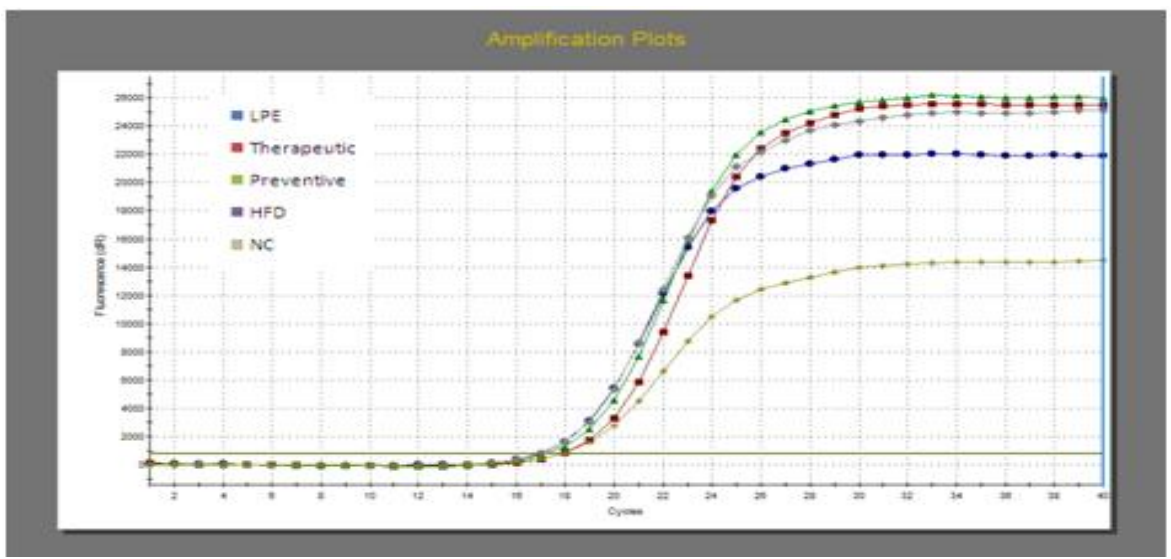

Fig (3): Amplification plots for ACO gene expression.

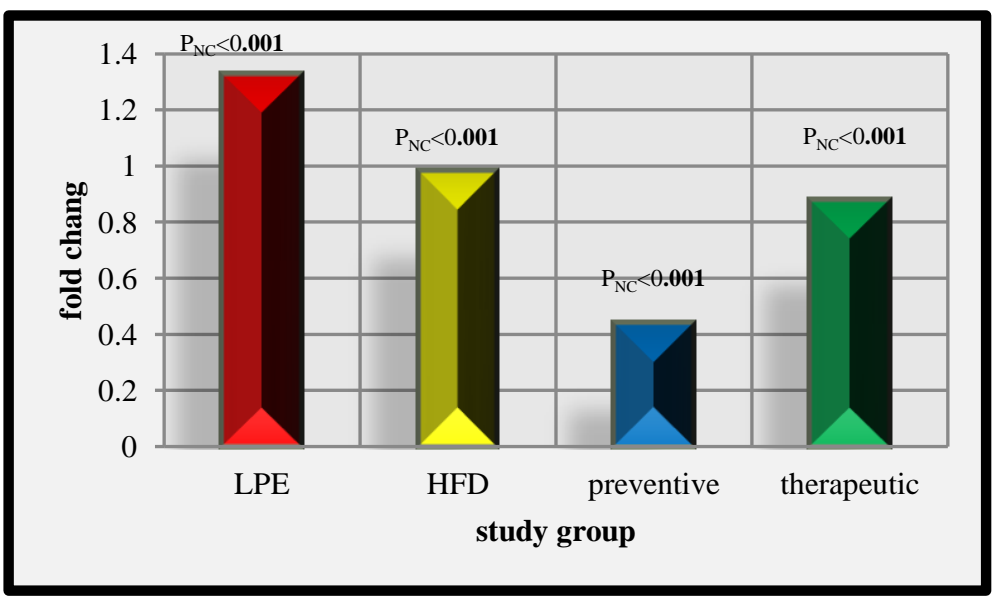

(A)

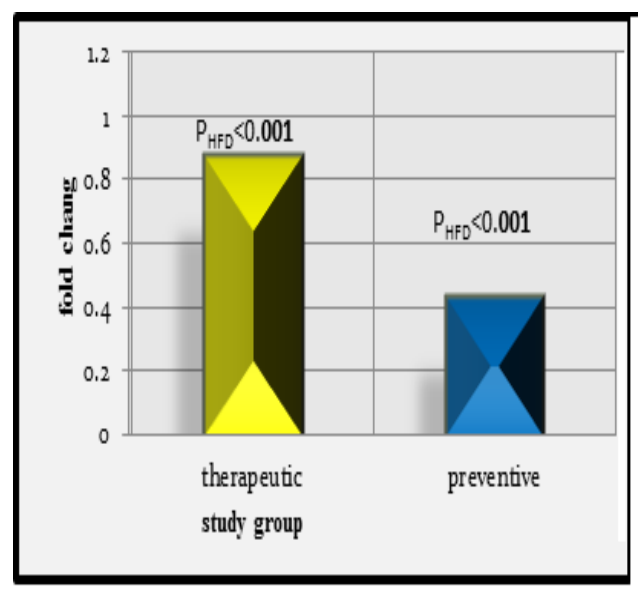

(B)

Fig (4): A) $\mathrm{P}_{\mathrm{NC}}$, the difference in ACO gene expression compaed to the normal control group. B) $\mathrm{P}_{\mathrm{HFD}}$, the difference in ACO gene expression compaed to the HFD-group.

Table 6: A) Fold change of ACO gene expression in the different groups relative to the normal control group.

\begin{tabular}{|c|c|c|c|c|c|}
\hline Groups & $\begin{array}{c}\text { Mean CT } \\
\text { Target gene }\end{array}$ & $\begin{array}{c}\text { Mean CT } \\
\text { Housekeeping } \\
\text { gene }\end{array}$ & $\Delta \mathbf{C T}$ & $\Delta \Delta \mathbf{C T}$ & $\begin{array}{c}\text { Equation } \\
\text { for fold } \\
\text { change } \\
\mathbf{2}^{-\Delta \Delta C \mathbf{C}}\end{array}$ \\
\hline LPE & 17.88 & 16.56 & 1.32 & -0.12 & 1.10 \\
\hline HFD & 17.44 & 16.98 & 0.98 & -0.46 & 1.38 \\
\hline Preventive & 17.86 & 16.86 & 0.44 & -0.99 & 1.99 \\
\hline Therapeutic & 17.54 & 16.98 & 0.88 & -0.56 & 1.48 \\
\hline
\end{tabular}

B) Fold change of ACO gene expression in the preventive and therapeutic groups relative to the HFD-group

\begin{tabular}{|c|c|c|c|c|c|}
\hline Groups & $\begin{array}{c}\text { Mean CT } \\
\text { Target gene }\end{array}$ & $\begin{array}{c}\text { Mean CT } \\
\text { Housekeeping } \\
\text { gene }\end{array}$ & $\Delta \mathbf{C T}$ & $\Delta \Delta \mathbf{C T}$ & $\begin{array}{c}\text { Equation for } \\
\text { fold change } \\
\mathbf{2}^{-\Delta \Delta \mathbf{C T}}\end{array}$ \\
\hline Preventive & 17.86 & 16.86 & 0.44 & -0.54 & 1.45 \\
\hline Therapeutic & 17.54 & 16.98 & 0.88 & -0.1 & 1.07 \\
\hline
\end{tabular}

LPE: Lemon peel extract.

HFD: High fat diet.

NC: Normal Control.

CT: Cycle threshold. 


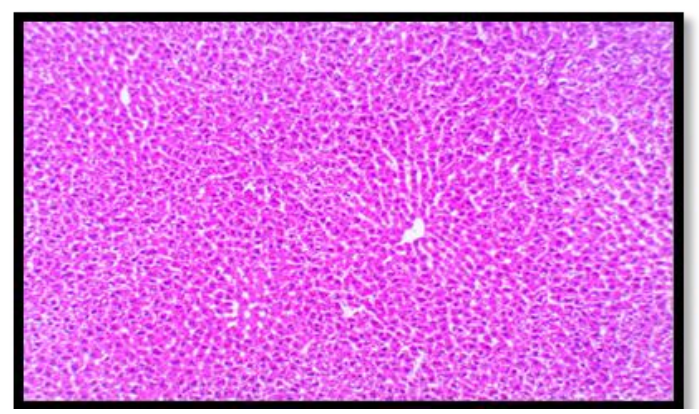

(A)

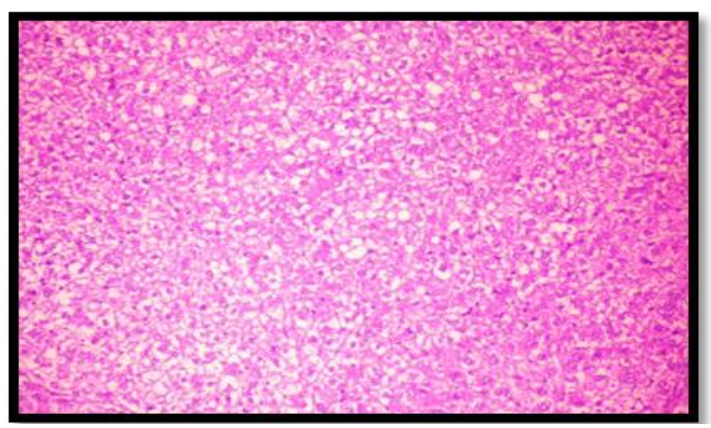

(C)

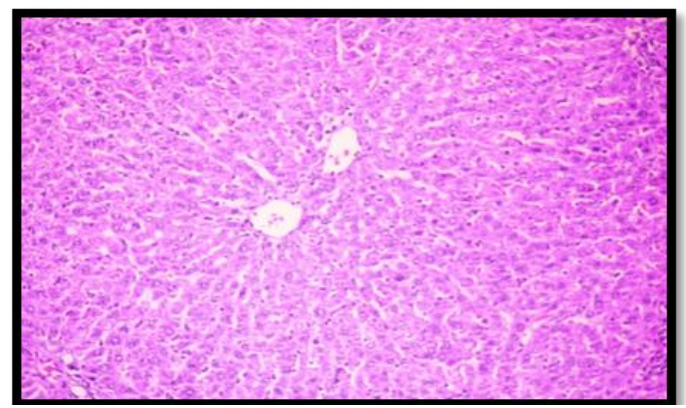

(B)

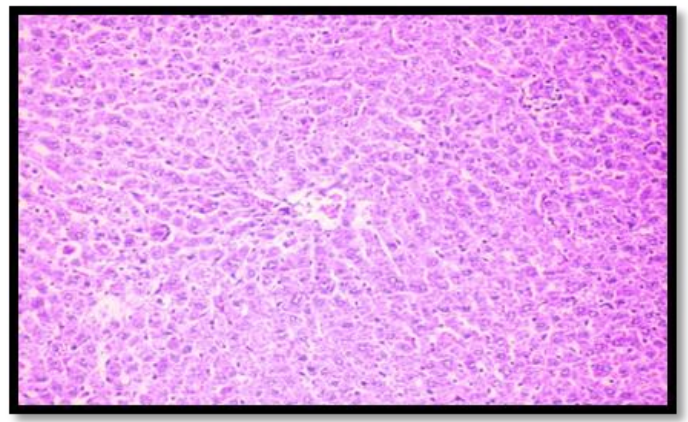

(D)

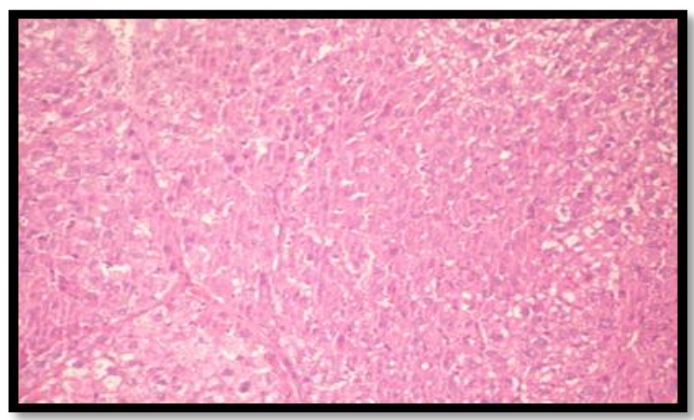

(E)

Fig. 5: Photomicrographs of H\&E X200-stained heptatocyte sections of (A) the normal histological structure of the hepatic lobule from the normal control rats; (B) the LPE-group showed a normal histological structure of the hepatic lobule; (C) the HFD-group showed diffuse glycogen infiltration; (D) the preventive group showed mild swelling and granularity of cytoplasm; (E) the therapeutic group showed focal areas of glycogen infiltration with narrowing of hepatic sinusoid.

In this study, the reduction of body weight and food intake revealed that supplementation with LPE in the preventive group as well as the therapeutic group reduced body weight and food intake as compared to the HFD-group (Table 2). This may be due to the effect of pyrogallic acid and quercetin in LPE. These results are in agreement with Shi et al. ${ }^{[37]}$ and Huang et al. ${ }^{[40]}$ who reported that quercetin (black tea extract) and pyrogallic acid (walnut polyphenols) decreased body weight and fat accumulation.

Abnormality in the metabolism of lipids and lipoproteins are very common conditions that take place in obese populations. The increase in total cholesterol may potentially enhance the risk of fatty liver and atherosclerosis ${ }^{[41]}$. Oxidized LDL has been shown to be atherogenic and inhibition of the LDL oxidation by potent dietary antioxidants effectively attenuates atherosclerosis ${ }^{[42]}$. Oral supplementation of LPE effectively enhanced obesity induced variation in lipid profile in rats fed high fat diet. In this context, the preventive effect of LPE was more pronounced than the therapeutic effect (Table 3). This may be attributed to the anti-obesity effect of polyphenols in LPE (especially pyrogallic acid, coumaric acid and quercetin), which have been shown to inhibit cholesterol absorption and biosynthesis and to promote the expression of LDLcholesterol receptors ${ }^{[37,}{ }^{43]}$. These findings were supported by the hepatic histological studies (Figs. 5 D and E) that showed reductions in hepatic lipid accumulation and fat vacuoles in LPE-treated groups. 
It has been reported that high fat diet known to increase the liver mitochondrial ROS production. ROS causes cell damage via the mechanism involving lipid peroxidation that leads to tissue injuries, especially in the liver ${ }^{[44]}$. In the current study the reduction in the levels of serum TAC (Table 4) together with the elevation in the lipid contents in the HFD-group of rats as compared to the normal control group indicated an increase in the lipid peroxidation rates. On the other hand, the increase in serum TAC resulted from the supplementation of LPE to the high fat diet either in preventive $(34.61 \%)$ or therapeutic groups $(30.77 \%)$ supported the antioxidant effect of its major component, pyrogallic $(39.1 \mathrm{mg} / 100 \mathrm{~g})$ rich in phenolic hydroxyl groups and consequently its ability to reduce oxidative stress. This finding confirmed that of Cui et al. ${ }^{[44]}$, Hatia et al. ${ }^{[45]}$ and Romelle et al. ${ }^{[46]}$ which showed that dietary polyphenols such as caffeic acid (Huangshan Maofeng green tea), $\rho$-coumaric acid, $\rho$-hydroxy benzoic acid, caffeic acid and quercetin (major dietary polyphenols) and quercetin (Statroltea) contain a number of phenolic hydroxyl groups and have demonstrated various beneficial effects, which is mainly due to their ROS scavenging activity.

The metabolic pathways of glucose and lipid metabolism in the liver are controlled by insulin, which regulates the hepatic glucose output and lipid synthesis ${ }^{[1]}$. With the increase in adipose tissue fat deposits, as in obesity, the ability of insulin to stimulate glucose transport and metabolism in adipocytes and skeleton muscle is impaired resulting in insulin resistance ${ }^{[47]}$. Therefore, any transformation in hepatic insulin sensitivity is rapidly reflected in glucose homeostasis and TG levels ${ }^{[48]}$. The observed reduction in the level of serum glucose, serum insulin and HOMA-IR in LPEtreated groups (Table 4) may be through depletion of the adipose tissue triglycerides stores that ultimately results in reductions of lipid levels due to the presence of quercetin, caffeic acid, $\rho$-hydroxy benzoic acid and $\rho$ coumaric acid in LPE which has direct effects on glucose metabolism, increasing insulin secretion and improving in insulin resistance ${ }^{[49]}$ and increased fatty acid $\beta$-oxidation pathway ${ }^{[50]}$.

Obese people are said to be resistant to the effects of leptin, in the same way that people with type 2 diabetes are resistant to the effects of insulin. The high sustained concentrations of leptin from the enlarged adipose stores result in leptin desensitization. The pathway of leptin control in obese people might be flawed at some points, so the body doesn't adequately receive the satiety feeling subsequent to eating ${ }^{[48]}$. In this study, the observed increases in serum insulin and leptin levels in rats fed high fat diet compared to those fed standard diet may be related to the fact that serum leptin levels are directly proportional to adipose tissue weight [51]. However, serum insulin and leptin were significantly reduced $(P<0.05)$ in LPE-treated groups, although the levels were higher than the normal control group (Table 4). These effects may be attributed to caffeic acid in
LPE probably through reduction in the expression level of leptin in white adipose tissue, improvement of insulin resistance and increased fatty acid $\beta$-oxidation pathway ${ }^{[52]}$. It is well known that circulating adiponectin levels are negatively correlated with obesity, particularly visceral obesity and insulin resistance ${ }^{[53]}$. Results of this study revealed the enhancment in adiponectin concentration found in LPE-fed groups relative to high fat group suggested that the expression and secretion of this adipokine was influenced by the reduced amount of body fat, leading to the decrease in the concentrations of plasma TG and TC ${ }^{[53]}$.

One of the enzymes of pentose phosphate pathway is G6PD which convert Glucose-6-phosphate into 6phosphglucono- $\delta$-lactone, that supplied reducing energy to cells (such as erythrocytes) by maintaining the level of the co-enzyme nicotinamide adenine dinucleotide phosphate (NADPH). NADPH is essential for the biosynthesis of fatty acid and cholesterol. Reduced activity of G6PD could limit the availability of fatty acids required for the synthesis of $\mathrm{TG}^{[49,53-54]}$. The NADPH in turn maintains the level of glutathione in these cells that helps protect the red blood cells against oxidative damage ${ }^{[53]}$. In the present study, the reduction in erythrocytes G6PD activity (Table 5) found in LPEtreated groups along with the reduction in TG and TC levels supported the antiobesity effect of LPE due to its content of $\rho$-hydroxy benzoic acid, $\rho$-coumaric acid, luteoline, caffeic acid and quercetin. These results are in agreement with Chung et al. ${ }^{[49]} \&$ Adem et al. ${ }^{[53]} \&$ Kumar et al. ${ }^{[54]}$ who stated that $\rho$-hydroxy benzoic acid, $\rho$-coumaric acid and caffeic acid (Cooked Giant Embryonic Rice), caffeic acid (some phenolic compound) and quercetin (Fenugreek Seed Extract) affects the pentose phosphate pathway by reducing G6PD activity, NADPH as a consequence; that is required for the biosynthesis of fatty acid and TC; leading to a rapid decline in fat stores.

In the last decade, it has become apparent that the expression of many lipid-metabolizing enzymes, including ACO and MCAD, is transcriptionally regulated by peroxisome proliferator-activated receptors (PPARs) ${ }^{[55]}$. Isoforms of PPAR family of nuclear receptors are involved in the systemic regulation of lipid metabolism and serve as a sensor for fatty acids, prostanoid metabolites, eicosanoids and related molecules ${ }^{[56]}$. In the present study, the significant elevations in serum ACO and MCAD activities (Table 5) in the high fat diet-group compared to the normal control group may be attributed to the increase of fatty acids that exert as an autoregulatory and coordinate effect over gene expression, that could target peroxisomal or mitochondrial $\beta$-oxidation enzymes ${ }^{[57]}$.

PPARs have many diverse functions, including the regulation of genes expression associated with glucose and lipid homeostasis ${ }^{[56]}$. The expressions of ACO and MCAD in liver, which play a key role in fatty acid oxidation, are regulated by several compounds derived from food such as flavonoids ${ }^{[58]}$. The dramatic increase 
in the activities of ACO and MCAD was more pronounced in the preventive group (1092.44 and $408.53 \%$, respectively) than the therapeutic group (699.18 and $184.30 \%$, respectively). In addition, ACO mRNA expression levels (Figs. 3 and 4) showed the same pattern with 2-fold increase in the preventive group and 1.5-fold increase in the therapeutic group. This may be due to the presence of quercetin and caffeic acid in LPE which are known to activate and elevate PPAR $\alpha$ and PPAR $\delta$ expression which are known to increase expression of ACO leading to elevated energy expenditure, subsequently resulting in anti-obesity actions ${ }^{[59]}$.

Conclusion: LPE may be a promising natural measure against obesity. The effect of LPE may protect rather than treat obesity consequently reducing risk of obesity associated diseases as atherosclerosis and diabetes mellitus. The mechanism of action by which LPE induces its anti-obesity effect may be related to decreasing lipid accumulation, enhancing insulin senstivity, total antioxidant capacity, downregulating G6PD activity while up-regulating of MCAD and ACO activities; and ACO mRNA expression level.

\section{References}

1) Tucakovic, L., Colson, N. and Singh, I. (2015). Relation between common dietary polyphenols and obesity-induced inflammation. Food and Public Health. 5(3): 84-91.

2) Balistreri, C. R., Caruso, C. and Candore, G. (2010). The role of adipose tissue and adipokines in obesity-related inflammatory diseases. Mediators of Inflammation. pp. 1-19. doi.org/10.1155/2010/ 802078.

3) Farrag, A., El-Eraky, A., El-Aroussy, W., Sayed, G., Mahrous, A., Adel, A., Ibrahim, A. M. and Ibrahim, M. (2015). Obesity and Other Cardiovascular Risk Factors in Egyptian University Students: Magnitude of the Problem. Epidemiology. 5:1.

4) Huang, T. W., Chang, C. L., Kao, E. S. and Lin, J. H. (2015). Effect of Hibiscus sabdariffa extract on high fat diet-induced obesity and liver damage in hamsters. Food Nutr. Res. 59: 29018.

5) Kang, J. G. and Park, C. Y. (2012). Anti-obesity drugs: a review about their effects and safety. Diabetes Metab. J. 36(1):13-25.

6) Nabavi, S. F., Russo, G. L., Daglia, M. and Nabavi, S. M. (2015). Role of quercetin as an alternative for obesity treatment: you are what you eat. Food Chem. 179: 305-310.

7) Jung, H. S., Lim, Y. and Kim, E. K. (2014). Therapeutic phytogenic compounds for obesity and diabetes. Int. J. Mol. Sci. 15: 21505-21537.

8) Yu, Y., Rajapakse, A. G., Montani, J-P., Yang, Z. and Ming, X-F. (2014). P38 mitogen-activated protein kinase is involved in arginase-II-mediated eNOS-Uncoupling in obesity. Cardiovasc Diabetol. 13(1): 113.

9) Garg, A., Anderson, R. A., Zaneveld, L. J. and
Garg, S. (2005). Biological activity assessment of a novel contraceptive antimicrobial agent. $\mathrm{J}$ Androl. 26: 414-421.

10) Gamboa-Gómez, C. I., Rocha-Guzmán, N. E., Gallegos-Infante, J. A., Moreno-Jiménez, M. R., Vázquez-Cabral, B. D. and González-Laredo, R. F. (2015). Plants with potential use on obesity and its complications. EXCLI Journal. 14: 809-831.

11) Fukunchi, Y., Hiramitsu, M., Okada, M., Hayashi, S., Nabeno, Y., Osawa, T. and Naito, M. (2008). Lemon Polyphenols Suppress Diet-induced Obesity by Up-Regulation of mRNA Levels of the Enzymes Involved in $\beta$-Oxidation in Mouse White Adipose Tissue. J Clin Biochem.Nutr. 43(3): 201-209.

12) Ezekwesili-Ofili, J. O. and Gwacham, N. C. (2015). Comparative effects of peel extract from Nigerian grown citrus on body weight, liver weight and serum lipids in rats fed a high-fat diet. African Journal of Biochemistry Research. 9(9): 110-116.

13) Kroyer, G. (2009). Antioxidant activity and total polyphenols in citrus fruit peels and seeds. Department of Natural Pro Food Chem. Publik.tuwien.ac.at/files/PubDat_178610.

14) Miyake, Y. (1997). Isolation of eriocitrin (eriodictyol 7-rutinoside) from lemon fruit (Citrus limon BURM. F.) and its antioxidative activity. Food Sci Technol Int. Tokyo. 3:84-89.

15) Perdetzoglou, D. K., Efthymiopoulos, C. and Harvala, C. (2000). A chemometric comparison of three Taxa of Scabiosa L.s. Plant Biosystems. 134(1):67-70.

16) Hosaya, N. (1980). Nutrition experiments using small animals. Tokyo Daiichi Shuppan. Japanese, p.71.

17) Naito, H. K. (1984a). Cholesterol. J Clin Chem. 437: 1194-1206.

18) Naito, H. K. (1984b). HDL Cholesterol. Clin Chem. 437: $1207-1213$.

19) Buccolo, G. and David, H. (1973). Quantitative determination of serum triglycerides by use of enzymes. Clin Chem. 19(5): 476-482.

20) Trinder, P. (1969). Glucose. Ann Clin Boichem. 6: 24-33.

21) Wilson, P. W., Garrison, R. J., Castelli, W. P., Feinleib, M., McNamara, P. M. and Kannel, W. B. (1980). Prevalence of coronary heart disease in the Framingham offspring study: role of lipoprotein cholesterol. Am. J Cardiol. 46(4): 649-654.

22) Friedewald, W. T., Levy, R. I. and Fredrickson, D. S. (1972). Estimation of the concentration of low density lipoprotein cholesterol in plasma without use of the ultracentrifugation. Clin Chem. 18: 499-509.

23) Delong, D. M., Delong, E. R., Wood, P. D., Lippel, K. and Rifkind, B. M. (1986). A comparison of methods for the estimation of plasma low- and very low-density lipoprotein cholesterol: the Lipid Research Clinics Prevalence Study. JAMA. 256(17): 2372-2377.

24) Meiattini, F. (1978). The 4- hydroxybenzoate/4aminophenazone chromogenicsystem. Clin. Chem., 
24(12):2161-2165.

25) Paintlia, A. S., Paintlia, M. K., Singh, A. K. and Singh, I. (2008). Inhibition of rho family functions by lovastatin promotes myelin repair in ameliorating experimental autoimmune encephalomyelitis. Mol. Pharmacol. 73(5):1381-93.

26) Matthews, D. R., Hosker, J. P., Rudenski, A. S., Naylor, B. A., Treacher, D. F. and Turner, R. C. (1985). Homeostasis model assessment: insulin resistance and beta-cell function from fasting plasma glucose and insulin concentrations in man. Diabetologia. 28(7): 412-419.

27) Nemzek, J. A., Siddiqui, J. and Remick, D. G. (2001). Development and optimization of cytokine ELISAs using commercial antibody pairs. J Immunol Methods. 255: 149-157.

28) Yamauchi, T., Kamon, J., Waki, H., Terauchi, Y., Kubota, N., Hara, N., Mori, Y., Ide, T. and Murakami, K. (2001). The fat-derived hormone adiponectin reverses insulin resistance associated with both lipoatrophy and obesity. Nature Medicine. 7(8):941-946.

29) Koracevic, D. (2001). Total antioxidant capacity. J Clin Pathol. 54(5): 356-361.

30) Kornberg, H. (1955). Determination of activity of glucose 6 phosphate Dehydrogenase by rate of reaction method. Method in Enzymology. 1: 323324.

31) Osumi, T., Ishii, N., Miyazawa, S. and Hashimoto, T. (1987). Isolation and structural characterization of the rat acyl-CoA oxidase gene. J. Biol. Chem. 262: 8138-8143.

32) Koster, K. L., Sturm, M., Herebian, D., Smits, S. H. and Spiekerkoetter, U. (2014). Functional studies of 18 heterologously expressed mediumchain acyl-CoA dehydrogenase (MCAD) variants. J Inherit Metab Dis. 37(6): 917-928.

33) Marko, N. F. (2004). RNA extraction from human or animal tissue samples. The institute for genomic research standard operating procedure. SOP \#: M019: 1-12. Ohlssen H, Edlund T (1986): Cell. 45: 35-44.

34) Ausubel, F. M., Brent, R., Kingston, R. E., Moore, D. D., Seidman, J. G., Smith, J. A. and Struhl, K. (1989). Current Protocols in Molecular Biology. John Wiley and Sons, Greene Publishing Associated, New York. Prepartive Biochemistry. 18(3): 337-378.

35) Longo, M. C., Berninger, M. S. and Hartley, J. L. (1990). Use of uracil DNA glycosylase to control carryover contamination in polymerase chain reactions. Gene. 93(1): 125-128.

36) Marrades, M. P., Milagro, F. I., Martinez, J. A. and Moreno-Aliaga, M. J. (2006). Differential expression of aquaporin 7 in adipose tissue of lean and obese high fat consumers. Biochem. Biophys Res Commun. 339: 785-789.

37) Shi, D., Chen, C., Zhao, S., Ge, F., Liu, D. and Song, H. (2014). Walnut polyphenols inhibit pancreatic lipase activity in vitro and have hypolipidemic effect on high fat diet-induced obese mice. Journal of Food and Nutrition Research. 2(10): 757-763.

38) Nathiya, S., Durga, M. and Devasena, T. (2014). Immunomodulatory and antioxidant actions of dietary flavonoids. Int J Pharma Pharma Sci. 6(2): 0975-1491.

39) Zych, M., Folwarczna, J. and Trzeciak, H. I. (2009). Natural phenolic acids may increase serum estradiol level in ovariectomized rats. Acta Biochem Polon. 56(3): 503-507.

40) Huang, Y. W., Liua, Y., Dushenkovb, S., Hoc, C. T. and Huanga, M. T. (2009). Anti-obesity effects of epigallocatechin-3-gallate, orange peel extract, black tea extract, caffeine and their combinations in a mouse model. Journal of Functional Foods. 1(3): 304-310.

41) Onat, A., Sari, I., Yazici, M., Can, G., Hergenc, G. and Avci, G. S. (2006). Plasma triglycerides, an independent predictor of cardiovascular disease in men: a prospective study based on a population with prevalent metabolic syndrome. Int $\mathbf{J}$ Cardiology. 108(1): 89-95.

42) Fuhrman, B. and Aviram, M. (2001). Flavonoids protect LDL from oxidation and attenuate atherosclerosis. Curr Opin Lipidol. 12(1): 41-8.

43) Jia, L., Liu, X. and Bai, Y. (2010). Short term effect of cocoa product consumption on lipid profile: a meta-analysis of randomized controlled trials. Am J Clin Nutr. 92(1): 218-225. doi: 10.3945/ajcn.2009. 28202.

44) Cui, Y., Yang, X., Lu, X., Chen, J. and Zhao, Y. (2014). Protective effects of polyphenols-enriched extract from Huangshan Maofeng green tea against $\mathrm{CCl}$-induced liver injury in mice. Chem Biol Interact. 220: $75-83$.

45) Hatia, S., Septembre-Malaterre, A., Le-Sage, F., Badiou-Bénéteau, A., Baret, P., Payet, B., Lefebvre d'hellencourt, C. and Gonthier, M. P. (2014). Evaluation of antioxidant properties of major dietary polyphenols and their protective effect on 3T3-L1 preadipocytes and red blood cells exposed to oxidative stress. Free Radic Res. 48(4): 387-401.

46) Romelle, F. D, Eyong, O. J. and Moses, M. C. (2014). Effect of Statroltea on lipid metabolism in rats fed on high fat diet. J of Food and Nutrition Sciences. 2(4): 99-104.

47) Reaven, G. M. (1995). Pathophysiology of insulin resistance in human disease. Physiol. Rev. 75(3): 473-486.

48) Koch, C. E., Lowe, C., Pretz, D., Steger, J., Williams, L. M. and Tups, A. (2014). High-Fat Diet Induces Leptin Resistance in Leptin-Deficient Mice. Journal of Neuroendocrinology. 26(2): 58-67.

49) Chung, S. I., Kim, T. H., Rico, C. W. and Kang, M. Y. (2014). Effect of instant cooked giant embryonic rice on body fat weight and plasma lipid profile in high fat-fed mice. Nutrients. 6(6): 22662278

50) Chemler, J. A., Lock, L. T., Koffas, M. A. and 
Tzanakakis, E. S. (2007). Standardized biosynthesis of flavan-3-ols with effects on pancreatic beta-cell insulin secretion. Appl Microbiol Biotechnol. 77(4): 797-807.

51) Janeckova, R. (2001). The role of leptin in human physiology and pathophysiology. Physiol Res. 50: 443-459.

52) Xu, Y., Zhang, M., Wu, T., Dai, S. D., Xu, J. and Zhou, Z. (2014). The anti-obesity effect of green tea polysaccharide, polyphenols and caffeine in rats fed with high-fat diet. Food Funct. 6(1): 297304.

53) Adem, S., Comakli, V., Kuzu, M. and Demirdag, R. (2014). Investigation of the effects of some phenolic compounds on the activities of Glucose-6phosphate dehydrogenase from human erythrocytes. J Biochem Molecular Toxicology. 28(11): 510-514.

54) Kumar, P., Bhandari, U. and Jamadagni, S. (2014). Fenugreek seed extract inhibit fat accumulation and ameliorates dyslipidemia in high fat diet induced obese rats. BioMed Research International. 2014, ID 606021, 11pages. http://dx.doi.org/10.1155/2014/606021.
55) Schoonjans, K., Staels, B. and Auwerx, J. (1996). Role of the Peroxisome proliferator-activated receptor (PPAR) in mediating the effects of fibrates and fatty acids on gene expression. J lipid Res. 37(5): 907-925.

56) Youssef, J. and Badr, M. (2015). Peroxisome Proliferator-Activated Receptors: Features, Functions, and Future. Nuclear Receptor Research. 2, Article ID 101188, 30 pages. doi:10.11131/2015/101188.

57) Ouali, F., Djouadi, F., Merlet-Benichou, C., Riveau, B. and Bastin, J. (2000). Regulation of fatty acid transport protein and mitochondrial and peroxisomal $\beta$-oxidation gene expression by fatty acids in developing rats. Pediatr Res. 48(5): 691-696.

58) Sugden, M. C., Caton, P. W. and Holness, M. J. (2010). PPAR control: it's SIRTainly as easy as PGC. Journal of Endocrinology. 204: 93-104.

59) Ali, F., Ismail, A. and Kersten, S. (2013). Molecular mechanisms underlying the potential antiobesity-related diseases effect of cocoa polyphenols. Mol Nutr Food Res. 58(1):33-48. doi: 10.1002/mnfr.201300277. 